\title{
PENGUATAN KAPASITAS LENTUR BETON DENGAN PEMANFAATAN LIMBAH
}

\section{Reinforcement Concrete Flexible Capacity Using Waste}

\author{
Dwi Kurniati \\ Prodi Teknik Sipil-Fakultas Sains dan Teknologi-Universitas Teknologi Yogyakarta \\ Kampus 2 UTY Jl. Glagahsari No. 63 Umbulharjo, Yogyakarta \\ email: dwi.kurniati@staff.uty.ac.id
}

\begin{abstract}
Nowadays there are so many construction in a region, then a problem occurred which is caused by the scarcity of material used in a construction. In order to minimize the scarcity of material it needed research about material waste as alternative materials that can be used in the construction work. The purpose of this research for knowing value of slump with added waste tile fragments and fly ash, and knowing the flexural strength of added waste tile fragments. This research was conducted at the Laboratory of Material on University of Islam Indonesia Yogyakarta, methods of this research used the flexural strength test. The percentage of added material used in this study was 5\%, 10\% and 15\%. This research used by the age of 14 and 28 days treatment. The quality of the planned concrete is $25 \mathrm{MPa}$. The highest percentage of the added material on the flexural strength test with added material is 5\%, during the 14 day testing obtained flexural strength values is 5,73 MPa. The highest percentage of the added material on the flexural strength test with added material is normally concrete, during the 28 day testing obtained flexural strength values is 5,93 MPa. Results of research for slump testing in normally concrete is $10,5 \mathrm{~cm}$, the variation of $5 \%$ is $14,4 \mathrm{~cm}$, the variation of $10 \%$ is $15,35 \mathrm{~cm}$ and the variation of $15 \%$ is $16 \mathrm{~cm}$. So it was concluded that the ingredients added to stone ash and tile were less recommended for use in construction, because the quality of the concrete produce is far from the concrete quality of plan.
\end{abstract}

Keywords: Concrete; Flexible; Fly Ash; Superplasticiser; Tile

\begin{abstract}
Abstrak
Dewasa ini semakin banyak pembangunan konstruksi dalam suatu wilayah. Kondisi ini yang menyebabkan timbulnya permasalahan pada kelangkaan material yang digunakan. Demi meminimalisir kelangkaan material, diperlukan penelitian mengenai pengolahan limbah material sebagai bahan tambah alternatif yang dapat digunakan dalam pekerjaan pembangunan konstruksi. Tujuan penelitian ini adalah untuk mengetahui nilai kelecakan pada campuran beton, dan nilai kuat lentur beton. Penelitian ini dilakukan di Laboratorium Bahan Universitas Islam Indonesia Yogyakarta, dengan metode pengujian uji lentur beton. Benda uji yang digunakan adalah sampel uji balok, dengan prosentase 5\%,10\% dan 15\%. Pengujian dilakukan pada umur beton 14 hari dan 28 hari. Mutu beton rencana adalah $25 \mathrm{MPa}$. Pada pengujian kuat lentur ratarata nilai tertinggi dengan umur 14 hari yaitu beton dengan bahan tambah 5\% sebesar 5,73 $\mathrm{MPa}$. sedangkan nilai rata-rata kuat lentur tertinggi di 28 hari yaitu beton normal sebesar 5,93 $\mathrm{MPa}$. Hasil dari pengujian nilai slump pada campuran beton normal yaitu $10,5 \mathrm{~cm}$, campuran dengan bahan tambah 5\% yaitu 14,4 cm, campuran beton dengan bahan tambah $10 \%$ yaitu $15,35 \mathrm{~cm}$ dan campuran beton dengan bahan tambah $15 \%$ yaitu $16 \mathrm{~cm}$. Sehingga didapatkan kesimpulan bahwa bahan tambah limbah pecahan genteng, fly ash dan superplasticiser kurang direkomendasikan untuk digunakan dalam konstruksi, dikarenakan mutu beton yang dihasilkan jauh dri mutu beton rencana.
\end{abstract}

Kata kunci: Abu; Beton; Genteng; Lentur; Superplasticiser 


\section{PENDAHULUAN}

Indonesia dalam beberapa periode sedang giat-giatnya membangun berbagai infrastuktur, mulai dari gedung sebagai fasilitas publik hingga jalan raya sebagai penghubung antar daerah.

Menurut Standar Nasional Indonesia (SNI 03-2847-2002), beton adalah campuran antara semen portland atau semen hidraulik lain, agregat halus, agregat kasar dan air dengan atau tanpa bahan tambahan yang membentuk massa padat. Material pembentuk beton tersebut dicampur merata dengan komposisi tertentu menghasilkan suatu campuran yang homogen sehingga dapat dituang dalam cetakan untuk dibentuk sesuai keinginan.

Abu batu adalah suatu partikel kecil yang cukup kasar dan berasal dari bongkahan atau pecahan dari batu yang biasa difungsikan sebagai agregat kasar untuk campuran beton.Sifat abu batu adalah mengikat dan semakin mengeras apabila terkena air, hal ini sangatlah bermanfaat untuk campuran beton. Oleh karena itu, abu batu diharapkan dapat digunakan untuk campuran beton guna meminimalisir penggunaan semen. Hal ini akan berimbas kepada pengurangan dalam pengeluaran material semen sebagai campuran beton.

Superplasticiser adalah suatu bahan kimia yang digunakan pada campuran beton yang bermanfaat untuk meningkatkan mutu beton dan mempercepat waktu pengeringan beton. Selain itu, dengan adanya superplasticiser maka dapat meminimalisir penggunaan semen terhadap campuran beton. Dalam penggunaan superplasticiser digunakan sesuai dengan kebutuhan.Terdapat berbagai jenis superplasticiser, ada yang bersifat memperkuat mutu beton, ada juga yang memperlambat proses pengeringan dan ada juga yang dapat mempercepat proses pengeringan campuran beton.

kondisi limbah bangunan yang tidak dimanfaatkan kembali dapat menyebabkan penumpukan sampah yang akan membantu perluasan global warming maka dari itu sangat diperlukan sikap reduce, recycle dan reuse dalam pengolahan limbah konstruksi. Pemaksimalan untuk material beton dapat diambil dari limbah beton, limbah bata, maupun limbah genteng. Salah satu pemaksimalan limbah yang dapat diolah adalah pecahan genteng.Pecahan genteng ini diharapkan dapat dimanfaatkan sebagai bahan campuran agregat, guna meminimalisir pemakaian krikil sebagai agregat kasar. Sehingga limbah bangunan dapat dimanfaatkan kembali, dan harapannya nilai mutu beton yang dihasilkan dari penambahan limbah ini dapat sesuai dengan mutu beton rencana yaitu $25 \mathrm{MPa}$.

Tujuan penelitian ini adalah untuk mengetahui nilai kelecakan pada campuran beton dan mengetahui nilai kuat lentur beton.

Terdapat beberapa penelitian terdahulu yang juga memanfaatkan limbah sebagai bahan substitusi agregat ataupun sebagai substitusi semen.

Alrutu Elkarsa Baeha, dkk., (2016), melakukan penelitian tentang pemanfaatan limbah genteng dan keramik sebagai agregat kasar campuran beton, dalam penelitian tersebut limbah genteng dan keramik akan digunakan sebagai pengganti agregat kasar dalam campuran beton. Beton terbentuk dari campuran semen, air, dan agregat dengan komposisi tertentu. Banyaknya konstruksi yang menggunakam bahan beton membuat kebutuhan material beton meningkat. Untuk itu, diperlukan inovasi untuk menyelesaikan masalah tersebut, salah satunya adalah dengan mengganti atau mengurangi jumlah material beton dengan memanfaatkan limbah yang ada. Pengujian beton bertujuan untuk mendapatkan beton mutu $35 \mathrm{MPa}$ dengan memanfaatkan limbah sebagai campuran material beton. Limbah yang dapat digunakan adalah puing bangunan, seperti pecahan genteng, keramik, ataupun pecahan batu bata. Puing bangunan digunakan sebagai pengganti agregat kasar sebanyak 20\% dari total bahan agregat kasar yang dibutuhkan. Puing bangunan yang digunakan berupa pecahan genteng dan keramik dengan ukuran maksimum agregat $20 \mathrm{~mm}$. Hasil perhitungan yang didapatkan dibagi dengan faktor pengali sesuai umur benda uji untuk mendapatkan nilai uji kuat tekan 28 hari. Rata-rata dari nilai uji kuat tekan 28 hari tersebut menunjukkan nilai kuat tekn beton. Dari perhitungan yang dilakukan, didapatkan nilai rata- rata hasil uji tekan untuk benda uji kubus sebesar 17,499 MPa dan untuk benda uji silinder sebesar 16,332 MPa.

Dewi Pertiwi (2011), melakukan penelitian mengenai perbandingan penggunaan pasir lumajang dengan pasir 
Gunung Merapi terhadap kuat tekan beton. Beton merupakan fungsi dari bahan penyusunnya yang terdiri dari bahan semen hidrolik, agregat kasar, agregat halus, air, dan bahan tambahan. Dalam penelitian ini ada dua jenis agregat halus yang dipergunakan yakni pasir lumajang dan pasir gunung merapi. Pasir gunung Merapi merupakan pasir dengan kualitas baik, dikarenakan partikelnya yang memiliki sudut. Pola partikel yang memiliki sudut itulah yang membuat ikatan pasir gunung merapi degan semen menjadi lebih kuat. Berdasarkan hal tersebut penelitian ini mencoba untuk melakukan perbandingan pasir lumajang dengan pasir gunung merapi terhadap kuat tekan beton. Metode pembuatan benda uji menggunakan beton silinder ( $\mathrm{cm}$, tinggi $30 \mathrm{~cm}$ ) dengan kuat tekan rencana $30 \mathrm{MPa}$, menggunakan variasi Faktor Air Semen (FAS) 0.6, 0.5, 0,4 dan 0,3 serta dicampurkan dengan Fly Ash 20\%. Dari hasil penelitian didapatkan hasil pada FAS 0,6 kuat tekan beton untuk pasir Lumajang sebesar 273,964 dan pasir Gunung Merapi 270,094 ini semua tidak memenuhi kuat tekan rencana yang memenuhi kuat tekan beton rencana yakni pada FAS 0,5 pasir Lumajang mengalami peningkatan sebesar $27 \%$ yakni $411,499 \mathrm{~kg} / \mathrm{cm}^{2}$, sedangkan pasir Gunung Merapi mengalami peningkatan sebesar $22,9 \%$ yakni $389,351 \mathrm{~kg} / \mathrm{cm}^{2}$. Pada FAS 0,4 pasir Lumajang mengalami peningkatan sebesar $32,6 \%$ yakni $445,728 \mathrm{~kg} / \mathrm{cm}^{2}$, sedangkan pasir Gunung Merapi mengalami peningkatan sebesar $36,5 \%$ yakni 472,716 $\mathrm{kg} / \mathrm{cm}^{2}$. Pada FAS 0,3 pasir Lumajang mengalami peningkatan sebesar $48,3 \%$ yakni $580,432 \mathrm{~kg} / \mathrm{cm}^{2}$, sedangkan Pasir Gunung Merapi mengalami peningkatan sebesar $54,7 \%$ yakni $663,224 \mathrm{~kg} / \mathrm{cm}^{2}$.

Iwan Wikana dan Wantutrianus 2014, melakukan penelitian tentang pengaruh pemakaian fly ash dan abu batu sebagai pengganti sebagian semen pada kuat tekan beton. suatu metode untuk meningkatkan kekuatan beton adalah dengan mengganti bagian dari semen dengan suatu campuran. Salah satu campuran untuk beton adalah abu terbang dan debu batu. Tujuan dari penelitian ini adalah untuk mengetahui proporsi optimum dari campuran sehubungan dengan jumlah semen, untuk menghasilkan kekuatan beton yang tinggi, yang didefinisikan oleh SK SNI T-28-1991-03 dengan memiliki kekuatan tekan beton $\geq 41,2$ benda uji uji silinder memiliki dimensi diameter $15 \mathrm{~cm}$ dan tinggi $30 \mathrm{~cm}$, disiapkan dengan proporsi fly ash dengan variasi $7,5 \%, 12,5 \%, 17,5 \% 22,5 \%$ dan $27,5 \%$ dari berat semen. Jumlah abu batu adalah $12,5 \%$ dari berat semen untuk semua proporsi abu terbang dan semen. Dengan faktor air semen 0,46 digunakan untuk semua benda uji. Enam variasi yang disiapkan untuk setiap proporsi campuran. Uji kuat tekan beton dilakukan ketika usia benda uji mencapai 28 hari. Kekuatan tekan betonnya dengan variasi benda uji tanpa campuran menghasilkan kuat tekan 36,48 MPa. Hasil pengujian menunjukkan bahwa campuran yang terdiri dari $22,5 \%$ abu terbang dan $12,5 \%$ abu batu untuk menggantikan semen dengan jumlah yang sama adalah proporsi optimum untuk diproduksi kekuatan tekan tertinggi dalam variasi, yaitu 48,30 MPa. Tampaknya menambahkan fly ash di luar 22,5\% menghasilkan efek buruk terhadap kualitas peningkatan dari campuran tersebut.

\section{METODE PENELITIAN}

Metode penelitian pada penelitian ini dilakukan dengan dua tahapan yaitu:

a. Tahap Persiapan

Pada tahapan ini dilakukan persiapan alat dan bahan material antara lain, pengujian terhadap agregat halus dan agregat kasar.

b. Tahap Pengujian

Pengujian kuat lentur beton dengan umur 14 hari dan 28 hari dengan masing-masing sampel uji sebanyak 3 buah perprosentasenya. Pembagian sampel uji tersebut adalah sebagai berikut, untuk umur 14 hari terdapat 3 sampel uji beton normal, 3 sampel uji beton bahan tambah dengan prosentase 5\%, 3 sampel uji beton bahan tambah dengan prosentase $10 \%$, 3 sampel uji beton bahan tambah dengan prosentase $15 \%$. Sedangkan untuk umur 28 hari terdapat 3 sampel uji beton normal, 3 sampel uji beton bahan tambah dengan prosentase $5 \%, 3$ sampel uji beton bahan tambah dengan prosentase $10 \%$, 3 sampel uji beton bahan tambah dengan prosentase $15 \%$. Sehingga total sampel uji sebanyak 24 pcs. Pengujian yang dilakukan ialah uji kuat tekan, dengan kuat tekan rencana sebesar $25 \mathrm{MPa}$. Pengujian dilakukan di Laboratorium Bahan Universitas Islam Indonesia Yogyakarta. Untuk urutan dan sistematika penelitian disampaikan dalam bentuk bagan alir penelitian yang dapat dilihat pada Gambar 1 . 


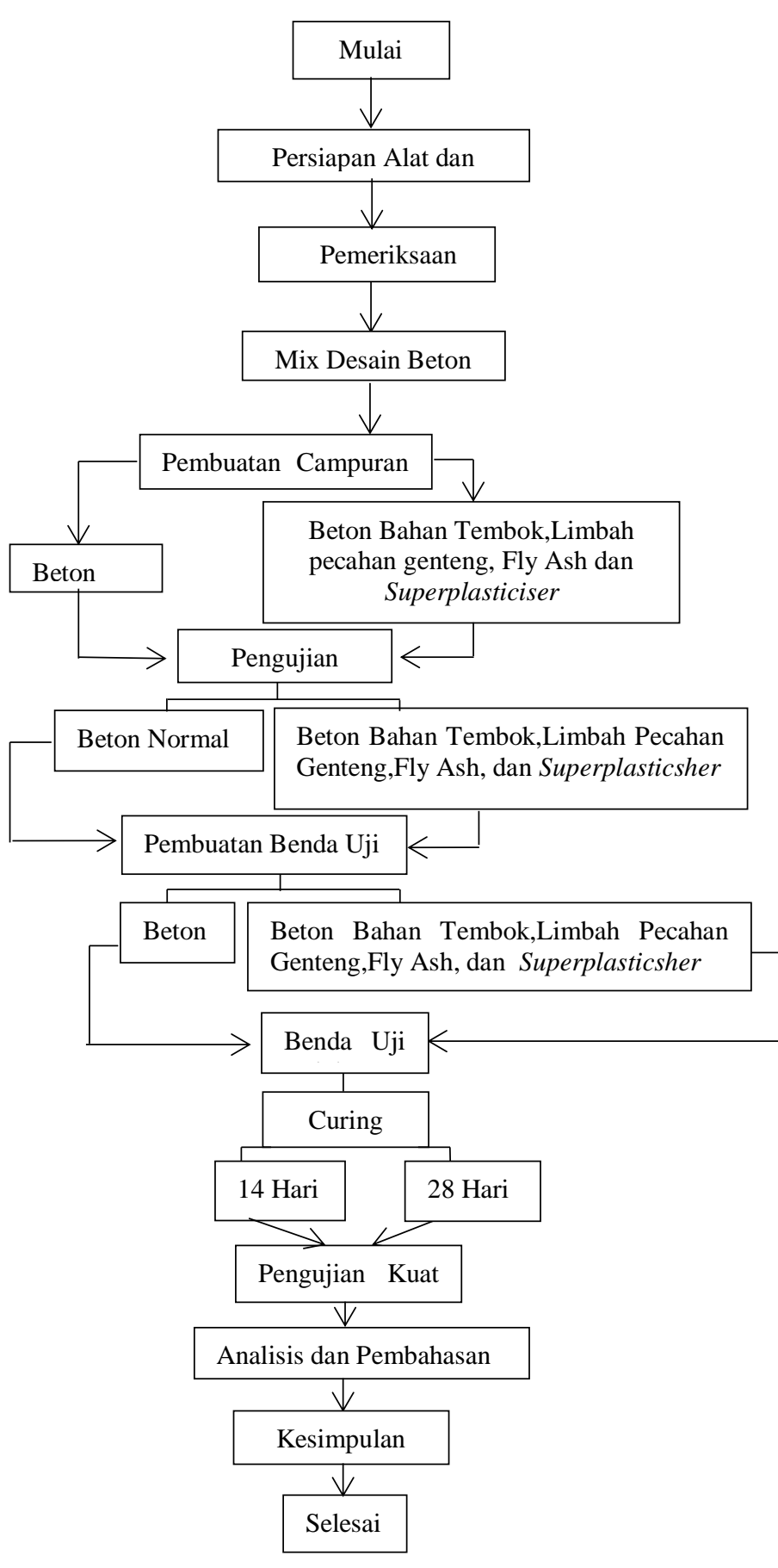

Gambar 1. Bagan Alir Metode Penelitian

\section{HASIL DAN PEMBAHASAN}

Berdasarkan (SNI 2847. 2013), (SNI 032834-2000), (SNI 03-1974-1990), (No Title), (PU), (Badan Standardisasi Nasional), didapatkan hubungan nilai kuat lentur beton pada penelitian ini direncanakan sesuai dengan mix design SNI $25 \mathrm{MPa}$ sehingga kuat lentur yang diperoleh sebesar 3,1 MPa. Pada penelitian ini didapatkan nilai kuat lentur beton pada tabel 1 dan gambar 2 dapat dilihat bahwa setelah dilakukan pengujian beton normal pada umur beton 14 hari didapatkan nilai kuat lentur beton sebesar 5,6 $\mathrm{MPa}$, sedangkan untuk nilai kuat lentur beton normal pada umur 28 hari didapatkan 5,93 MPa. Pada pengujian kuat lentur beton dengan bahan tambah 5\% abu batu dan 5\% pecahan genteng pada umur 14 hari didapatkan 5,73 $\mathrm{MPa}$, sedangkan pada umur 28 hari pengujian beton didapatkan nilai kuat lentur beton sebesar 5,63 MPa. Pada pengujian kuat lentur beton dengan bahan tambah $10 \%$ abu batu dan $10 \%$ pecahan genteng pada umur 14 hari didapatkan 5,46 MPa, sedangkan pada umur 28 hari pengujian beton didapatkan nilai kuat lentur beton sebesar 5,67 MPa. Pada pengujian kuat lentur beton dengan bahan tambah $15 \%$ abu batu dan $15 \%$ pecahan genteng pada umur 14 hari didapatkan 5,67 MPa, sedangkan pada umur 28 hari pengujian beton didapatkan nilai kuat lentur beton sebesar 5,48 MPa.

Jika dibandingkan antara beton normal dengan beton yang menggunakan bahan tambah $5 \%$ abu batu dan $5 \%$ pecahan genteng, $10 \%$ abu batu dan $10 \%$ pecahan genteng, $15 \%$ abu batu dan $15 \%$ pecahan genteng maka nilai kuat lentur beton tertinggi pada umur 14 hari yaitu beton normal sebesar 5,6 MPa, begitu juga dengan beton normal pada umur 28 hari yaitu sebesar 5,93 Mpa. Untuk nilai kuat lentur beton tertinggi pada umur 14 hari dengan bahan tambah abu batu dan pecahan genteng, maka nilai kuat lentur beton tertinggi yaitu dengan bahan tambah $5 \%$ abu batu dan $5 \%$ pecahan genteng sebesar 5,73 MPa, begitu juga dengan beton pada umur 28 hari sebesar 5,63 MPa. Untuk beton dengan bahan tambah $5 \%$ pecahan genteng dan $5 \%$ abu batu memiliki nilai kuat lentur beton tertinggi untuk beton dengan bahan tambah, hal tersebut dikarenakan pada saat pengujian kuat lentur beton benda uji akan mudah patah pada bagian beton yang terdapat pecahan genteng maka dari itu ketika beton dengan bahan tambah $15 \%$ pecahan genteng akan mudah patah. 
Tabel 1. Hasil Pengujian Kuat Lentur Beton

\begin{tabular}{|c|c|c|c|c|c|c|c|}
\hline NO & Jenis Beton & Kode Beton & $\begin{array}{c}\text { Berat } \\
\text { Beton } \\
(\mathrm{Kg})\end{array}$ & $\begin{array}{l}\text { Umur } \\
\text { Beton } \\
\text { (Hari) }\end{array}$ & $\begin{array}{c}\text { Beban } \\
\text { Maksimum (Kn) }\end{array}$ & $\begin{array}{l}\text { Kuat } \\
\text { Lentur } \\
\text { (Mpa) }\end{array}$ & $\begin{array}{l}\text { Rata- } \\
\text { Rata } \\
(\mathrm{Mpa})\end{array}$ \\
\hline 1 & \multirow{6}{*}{$\begin{array}{l}\text { Beton } \\
\text { Normal }\end{array}$} & BN-14-1 & 32.78 & 14 & 30 & 5.3 & \multirow{3}{*}{5.6} \\
\hline 2 & & BN-14-2 & 32.58 & 14 & 35 & 6.2 & \\
\hline 3 & & BN-14-3 & 32.87 & 14 & 30 & 5.3 & \\
\hline 4 & & BN-28-1 & 33.30 & 28 & 35 & 6.2 & \multirow{3}{*}{5.93} \\
\hline 5 & & BN-28-2 & 32.59 & 28 & 32.5 & 5.8 & \\
\hline 6 & & BN-28-3 & 31.00 & 28 & 32.5 & 5.8 & \\
\hline 7 & \multirow{6}{*}{$\begin{array}{l}\text { Beton Bahan } \\
\text { Tambah 5\% } \\
\text { Abu Batu dan } \\
\text { 5\% Pecahan } \\
\text { Genteng }\end{array}$} & BG-5-14-1 & 32.58 & 14 & 35 & 6.2 & \multirow{3}{*}{5.73} \\
\hline 8 & & BG-5-14-2 & 32.20 & 14 & 32 & 5.7 & \\
\hline 9 & & BG-5-14-3 & 30.53 & 14 & 30 & 5.3 & \\
\hline 10 & & BG-5-28-1 & 32.68 & 28 & 31 & 5.5 & \multirow{3}{*}{5.63} \\
\hline 11 & & BG-5-28-2 & 31.68 & 28 & 32.5 & 5.8 & \\
\hline 12 & & BG-5-28-3 & 29.74 & 28 & 31.5 & 5.6 & \\
\hline 13 & \multirow{6}{*}{$\begin{array}{l}\text { Beton Bahan } \\
\text { Tambah } 10 \% \\
\text { Abu Batu dan } \\
\text { 10\% Pecahan } \\
\text { Genteng }\end{array}$} & BG-10-14-1 & 32.87 & 14 & 32.5 & 5.8 & \multirow{3}{*}{5.46} \\
\hline 14 & & BG-10-14-2 & 31.04 & 14 & 30 & 5.3 & \\
\hline 15 & & BG-10-14-3 & 32.60 & 14 & 30 & 5.3 & \\
\hline 16 & & BG-10-28-1 & 32.50 & 28 & 33.35 & 5.9 & \multirow{3}{*}{5.67} \\
\hline 17 & & BG-10-28-2 & 32.35 & 28 & 32.5 & 5.8 & \\
\hline 18 & & BG-10-28-3 & 32.75 & 28 & 30 & 5.3 & \\
\hline 19 & \multirow{6}{*}{$\begin{array}{l}\text { Beton Bahan } \\
\text { Tambah } 15 \% \\
\text { Abu Batu dan } \\
\text { 15\% Pecahan } \\
\text { Genteng }\end{array}$} & BG-15-14-1 & 32.39 & 14 & 32.5 & 5.8 & \multirow{4}{*}{5.63} \\
\hline 20 & & BG-15-14-2 & 30.97 & 14 & 29 & 5.2 & \\
\hline 21 & & BG-15-14-3 & 30.96 & 14 & 33.5 & 6.0 & \\
\hline 22 & & BG-15-28-1 & 32.12 & 28 & 30.5 & 5.4 & \\
\hline 23 & & BG-15-28-2 & 31.64 & 28 & 30 & 5.3 & \multirow[t]{2}{*}{5.48} \\
\hline 24 & & BG-15-28-3 & 30.93 & 28 & 32 & 5.7 & \\
\hline
\end{tabular}

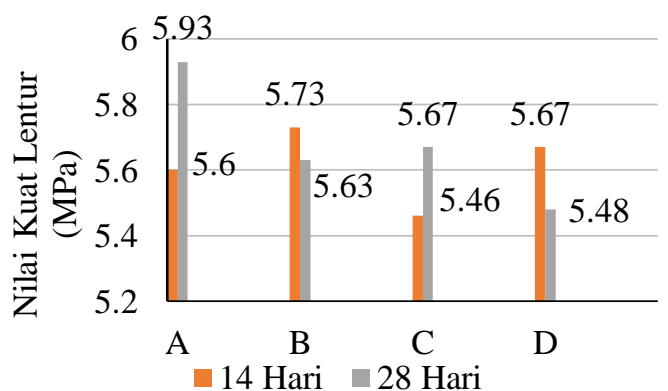

$\mathrm{A}=$ Beton Normal

$\mathrm{B}=$ Beton Bahan Tambah 5\% Abu Batu dan 5\% Pecahan Genteng

$\mathrm{C}=$ Beton Bahan Tambah 10\% Abu Batu dan $10 \%$ Pecahan Genteng

$\mathrm{D}=$ Beton Bahan Tambah 15\% Abu Batu dan $15 \%$ Pecahan Genteng

Gambar 2. Grafik Pengujian Kuat Lentur Beton

\section{KESIMPULAN DAN SARAN}

\section{Kesimpulan}

Pengunaan superplasticiser SikamentLN dapat meningkatkan nilai slump dan dapat memudahkan pengerjaan pada proses pengecoran beton, dalam penggunaan campuran superplasticiser $2 \%$ pada beton dengan bahan tambah abu batu dan pecahan genteng sebesar $5 \%$ yaitu sebesar $14,4 \mathrm{~cm}$, sedangkan pada dengan bahan tambah abu batu dan pecahan genteng sebesar $10 \%$ yaitu $15,35 \mathrm{~cm}$ dan dengan bahan tambah sebesar $15 \%$ yaitu $16 \mathrm{~cm}$. Sedangkan nilai slump pada beton normal tanpa penambahan superplasticiser memiliki nilai slump $10,5 \mathrm{~cm}$.

Nilai kuat lentur dengan mengunakan bahan tambahan abu batu, pecahan genteng dan superplasticiser Sikament-LN lebih rendah dibandingkan beton normal. Nilai kuat lentur beton normal maksimum pada umur 14 
hari sebesar 5,6 MPa, sedangkan pada umur 28 hari sebesar 5,93 MPa. Nilai kuat lentur beton dengan bahan tambah maksimum yaitu dengan bahan tambah abu batu 5\%, pecahan genteng 5\% dan superplasticiser SikamentLN 2\% pada umur 14 hari sebesar 5,73 MPa, sedangkan pada umur 28 hari sebesar 5,63 $\mathrm{MPa}$.

\section{Saran}

Pelaksanaan penelitian penggunaan limbah pecahan genteng dan abu batu terhadap kuat lentur beton, ditemukan beberapa kendala dalam proses pelaksanaannya. Bahan masukkan untuk penelitian yang akan datang antara lain sebagai berikut:

- Untuk memperoleh benda uji yang baik perlu diperhatikan dalam pemilihan mutu bahan material untuk campuran beton, dan perlu diperhatikan juga proses pembuatan benda uji. Dalam proses pemadatan campuran beton pada cetakan apabila tidak dilakukan dengan baik maka dapat menyebabkan adanya benda uji yang keropos sehingga dapat berpengaruh pada nilai kuat lentur beton beton.

- Pada saat pengujian benda uji lebih baik menggunakan alat uji yang memiliki pembacaan digital sehingga didapatkan hasil yang lebih akurat, dan dapat mengurangi adanya kesalahan pada saat pembacaan hasil pengujian.

- Untuk penelitian selanjutnya dapat dikembangkan dengan menjadikan limbah pecahan genteng menjadi abu pecahan genteng dengan menggerus atau menghancurkan pecahan genteng menjadi abu. Selain itu dengan membedakan presentase masing-masing bahan tambah, sehingga dapat menghasilkan nilai kuat tekan beton yang berbeda dan lebih baik lagi.

\section{DAFTAR PUSTAKA}

Baeha. A.E, dkk. (2016). Pemaksimalan limbah genteng dan keramik sebagai agregat kasar campuran beton K-350. Jurnal Teknik dan Ilmu Komputer. Jurusan
Teknik Sipil Universitas Kristen Krida Wacana. Jakarta Barat.

Badan Standarisasi Nasional. (1990). SNI 031974-1990 Metode Pengujian Kuat Tekan Beton. pp. 2-6. Balitbang PU.

Badan Standarisasi Nasional. (1997). SNI No 03-4431-1997 Metode Pengujian Kuat Lentur Normal Dengan Dua Titik Pembebanan.. Jakarta: Badan Standarisasi Nasional.

Badan Standarisasi Nasional. (2000). SNI 032834-2000 Tata Cara Pembuatan Rencana Campuran Beton Normal. pp. 1-34. Bandung: Badan Standardisasi Nasional.

Badan Standar Nasional. (2002). SNI No 032847-2002 Tata Cara Perhitungan Beton Untuk Bangunan Gedung. Jakarta: Badan Standarisasi Nasional.

Badan Standar Nasional. (2008). SNI No Nomor 4156:2008 Cara Uji Slump. Jakarta: Badan Standarisasi Nasional.

Badan Standarisasi Nasional. (2012). SNI 031726-2012 Tata Cara Perencanaan Ketahanan Gempa Untuk Bangunan Gedung. Bandung: Badan Standarisasi Nasional.

Badan Standarisasi Nasional. (2013). SNI 2847 Persyaratan Beton Struktural Untuk Bangunan Gedung. pp. 1-265. Bandung: Badan Standardisasi Indonesia.

Dewi. P., dkk. (2011). Perbandingan Penggunaan Pasir Lumajang Dengan Pasir Gunung Merapi Terhadap Kuat Tekan Beton. Jurnal APLIKASI. Jurusan Teknik Sipil Program Diploma Institut Teknologi Sepuluh Nopember. Surabaya.

Puslitbang PU (2002). Untuk Struktur Bangunan Gedung. Vol. 7798393, no. April, 2002.

Wikana. I., Wantutrianus. Z. (2014). Pengaruh Pemakaian Fly Ash Abu Batu Sebagai Pengganti Sebagian Semen Pada Kuat Tekan Beton Mutu Tinggi. Majalah Ilmiah UKRIM. Edisi 1. Jurusan Teknik Sipil Universitas Kristen Immanuel Yogyakarta. Yogyakarta. 